\title{
The Effective Catalyst (Cobalt Salt/Lewis Acid) for Beckmann Rearrangement of Cycloalkanone Oximes to Lactams under Mild Conditions
}

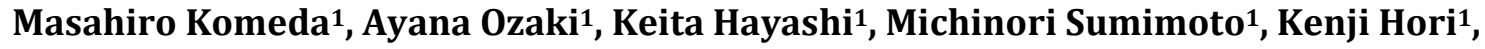 \\ Tsunemi Sugimoto ${ }^{2}$, Hidetoshi Yamamoto ${ }^{*}$ \\ ${ }^{1}$ Graduate School of Science and Engineering, Yamaguchi University, Ube, Japan \\ ${ }^{2}$ Ube Laboratory, Ube Industries, Ltd., Ube, Japan

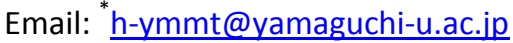

Received 22 April 2015; accepted 22 May 2015; published 25 May 2015

Copyright @ 2015 by authors and Scientific Research Publishing Inc.

This work is licensed under the Creative Commons Attribution International License (CC BY).

http://creativecommons.org/licenses/by/4.0/

(c) ()

\begin{abstract}
The Beckmann rearrangement of cyclohexanone oxime was achieved by the combined use of cobalt salt and Lewis acids co-catalysts (each $10 \mathrm{~mol} \%$ ). Various combinations of cobalt salts and Lewis acids gave lactams in a satisfactory yield under mild conditions. This method makes it possible to reduce undesirable byproducts.
\end{abstract}

\section{Keywords}

Beckmann Rearrangement, Cycloalkanone Oximes, Lactam, Cobalt Catalysts, Lewis Acids

\section{Introduction}

The Beckmann rearrangement is commonly used in organic chemistry to transform ketoximes into amides [1]-[9]. The reaction generally requires high reaction temperatures and strongly acids. Its reaction mechanism is typically described as an acid-catalyzed reaction, but an excessive number of acids are used in a practical way, and this reaction produces large numbers of byproducts [10]. It is generally said that $1.6-4.4$ tons of ammonium sulfate are formed to obtain one ton of $\varepsilon$-caprolactam. In recent years, 2,4,6-trichloro-1,3,5-triazine (cyanuric chloride) [11]-[13] and 1,3,5-triazo-2,4,6-triphosphorine-2,2,4,4,6,6-chloride (triphosphazene) [14] have been reported as catalysts for sulfate-free Beckmann rearrangements. Unfortunately, those catalysts do not give satisfactory results in the reaction of cyclohexanone oxime. One of the best ways to sulfate-free production of $\varepsilon$-ca-

\footnotetext{
*Corresponding author.
}

How to cite this paper: Komeda, M., Ozaki, A., Hayashi, K., Sumimoto, M., Hori, K., Sugimoto, T. and Yamamoto, H. (2015) The Effective Catalyst (Cobalt Salt/Lewis Acid) for Beckmann Rearrangement of Cycloalkanone Oximes to Lactams under Mild Conditions. International Journal of Organic Chemistry, 5, 57-62. http://dx.doi.org/10.4236/ijoc.2015.52007 
prolactam can be vapor-phase methods using various zeolite catalysts [15], but a perceived disadvantage of this route is to require a reaction temperature as high as $350^{\circ} \mathrm{C}$. To overcome the energy cost explosion and reactor heat deterioration problems, more economic and environmentally-friendly processes have been developed. We report here that cobalt salts are highly effective catalysts for the Beckmann rearrangement of cyclohexanone oxime under mild conditions.

\section{Results and Discussion}

The Beckmann rearrangement of cyclohexanone oxime (1) to $\varepsilon$-caprolactam (2) was examined using Lewis acids (Scheme 1 and Table 1). Most metal salts (each 10 mol\%) have no producing ability for the Beckmann rearrangement of $\mathbf{1}$ in $\mathrm{MeCN}$ at $80^{\circ} \mathrm{C}$ for $2 \mathrm{~h}$, several cobalt salts gave the corresponding lactam 2 with an unsatisfactory yield. Cyclohexanone (3) is considered to be a byproduct produced by hydrolysis of cyclohexanone oxime (1).

In order to clarify the catalytic ability of cobalt salts to the Beckmann rearrangement of oxime $\mathbf{1}$, we examined the effect of the amount of cobalt salts in this transformation (Table 2). As the amount of cobalt salts increased, the ratio of lactam $\mathbf{2}$ to oxime $\mathbf{1}$ increased. However, these results might be suggested that it was quite difficult to develop a "catalytic" process for a sulfate-free Beckmann rearrangement of oxime $\mathbf{1}$ using these cobalt salts under these conditions.

The plausible reaction mechanism of acid-catalyzed Beckmann rearrangement [16] of cyclohexanone oxime (1) to $\varepsilon$-caprolactam (2) may be speculated, the $N$-protonated cyclohexanone oxime (4) may be more stable than $O$-protonated cyclohexanone oxime (5) and the high energy transition state between $\mathbf{4}$ and $\mathbf{5}$ will make remarkably difficult to complete the rearrangement (Figure 1) [17]. If the same phenomenon has happened in a metal salt-catalyzed rearrangement, the nitrogen atom of the oxime $\mathbf{1}$ would have been protected against the added

Lewis acid for the rearrangement. We focused on a high nitrogen affinity of cobalt ions [18] to heighten the interaction between the Lewis acid added in order to promote a rearrangement reaction and the oxygen atom of the oxime 1.

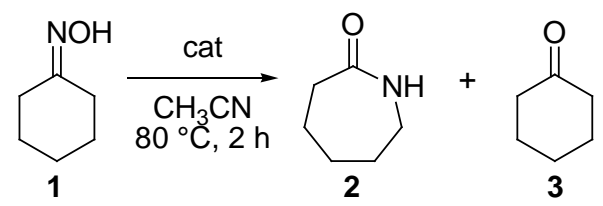

Scheme 1. Beckmann rearrangement of cyclohexanone oxime (1) to $\varepsilon$-caprolactam (2).

Table 1. Lewis acid-catalyzed Beckmann rearrangement of $\mathbf{1}^{\mathrm{a}}$.

\begin{tabular}{cccccc}
\hline \multirow{2}{*}{ Entry } & Lewis acid & & Yield/\% & & Selectivity \\
\cline { 3 - 5 } & & $\mathbf{2}$ & $\mathbf{3}$ & $\mathbf{1}$ & $\mathbf{2} / \mathbf{3} / \mathbf{1}$ \\
\hline 1 & $\mathrm{Yb}(\mathrm{OTf})_{3}$ & 4.8 & 0.0 & 79.1 & $5.7 / 0.0 / 94.3$ \\
2 & $\mathrm{Sm}(\mathrm{OTf})_{3}$ & 1.2 & 0.0 & 76.6 & $1.5 / 0.0 / 98.5$ \\
3 & $\mathrm{ZnCl}_{2}$ & 0.0 & 4.9 & 59.2 & $0.0 / 7.6 / 92.4$ \\
4 & $\mathrm{MgBr}_{2}$ & 0.0 & 0.0 & 59.9 & $0.0 / 0.0 / 100.0$ \\
5 & $\mathrm{NiBr}_{2}$ & 3.1 & 0.0 & 39.4 & $7.3 / 0.0 / 92.7$ \\
6 & $\mathrm{Ni}(\mathrm{acac})_{3}$ & 0.0 & 0.0 & 86.6 & $0.0 / 0.0 / 100.0$ \\
7 & $\mathrm{Co}\left(\mathrm{BF}_{4}\right)_{2} \cdot 6 \mathrm{H}_{2} \mathrm{O}$ & 10.3 & 0.0 & 32.0 & $24.3 / 0.0 / 75.7$ \\
8 & $\mathrm{CoCO}_{3}$ & 0.0 & 1.8 & 81.4 & $0.0 / 2.2 / 97.8$ \\
9 & $\mathrm{Co}\left(\mathrm{ClO}_{4}\right)_{2} \cdot 6 \mathrm{H}_{2} \mathrm{O}$ & 8.2 & 0.0 & 40.1 & $16.9 / 0.0 / 83.1$ \\
10 & $\mathrm{Co}\left(\mathrm{NO}_{3}\right)_{2} \cdot 6 \mathrm{H}_{2} \mathrm{O}$ & 1.4 & 30.5 & 29.6 & $4.0 / 13.8 / 82.2$ \\
\hline
\end{tabular}

${ }^{\mathrm{a}} \mathrm{A}$ mixture of cyclohexanone oxime $(0.5 \mathrm{mmol})$ and Lewis acid $(10 \mathrm{~mol} \%)$ was stirred in $\mathrm{MeCN}(1.0 \mathrm{~mL})$ at $80^{\circ} \mathrm{C}$ for $2 \mathrm{~h}$. 


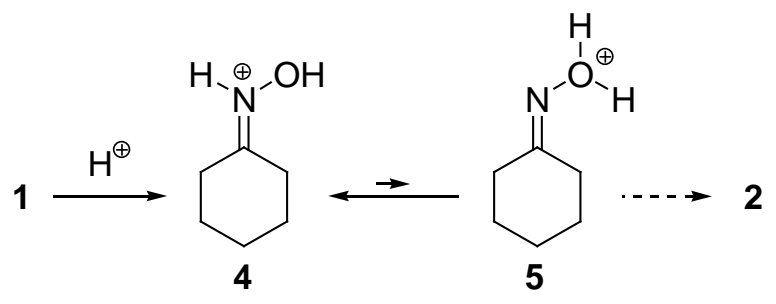

Figure 1. Protonation of cyclohexanone oxime (1).

Table 2. Effect of the amount of cobalt perchlorate and tetrafluoroborate ${ }^{\mathrm{a}}$.

\begin{tabular}{|c|c|c|c|c|}
\hline \multirow{2}{*}{ Entry } & \multirow{2}{*}{ Cobalt salt (mol\%) } & \multicolumn{2}{|c|}{ Yield/\% } & \multirow{2}{*}{$\begin{array}{c}\text { Selectivity } \\
\text { 2/1 }\end{array}$} \\
\hline & & 2 & 1 & \\
\hline 1 & $\mathrm{Co}\left(\mathrm{ClO}_{4}\right)_{2} \cdot 6 \mathrm{H}_{2} \mathrm{O}(10)$ & 8.2 & 40.1 & 16.9/83.1 \\
\hline 2 & $\mathrm{Co}\left(\mathrm{ClO}_{4}\right)_{2} \cdot 6 \mathrm{H}_{2} \mathrm{O}(25)$ & 39.1 & 18.0 & $68.5 / 31.5$ \\
\hline 3 & $\mathrm{Co}\left(\mathrm{ClO}_{4}\right)_{2} \cdot 6 \mathrm{H}_{2} \mathrm{O}(50)$ & 52.4 & 7.8 & $87.0 / 13.0$ \\
\hline 4 & $\mathrm{Co}\left(\mathrm{ClO}_{4}\right)_{2} \cdot 6 \mathrm{H}_{2} \mathrm{O}(75)$ & 61.7 & 4.0 & 93.9/6.1 \\
\hline 5 & $\mathrm{Co}\left(\mathrm{ClO}_{4}\right)_{2} \cdot 6 \mathrm{H}_{2} \mathrm{O}(100)$ & 71.5 & 0.0 & $100.0 / 0.0$ \\
\hline 6 & $\mathrm{Co}\left(\mathrm{BF}_{4}\right)_{2} \cdot 6 \mathrm{H}_{2} \mathrm{O}(10)$ & 10.3 & 32.0 & $24.3 / 75.7$ \\
\hline 7 & $\mathrm{Co}\left(\mathrm{BF}_{4}\right)_{2} \cdot 6 \mathrm{H}_{2} \mathrm{O}(25)$ & 44.8 & 12.2 & $78.6 / 21.4$ \\
\hline 8 & $\mathrm{Co}\left(\mathrm{BF}_{4}\right)_{2} \cdot 6 \mathrm{H}_{2} \mathrm{O}(50)$ & 62.3 & 7.4 & $89.4 / 10.6$ \\
\hline 9 & $\mathrm{Co}\left(\mathrm{BF}_{4}\right)_{2} \cdot 6 \mathrm{H}_{2} \mathrm{O}(75)$ & 66.1 & 0.0 & $92.4 / 7.6$ \\
\hline 10 & $\mathrm{Co}\left(\mathrm{BF}_{4}\right)_{2} \cdot 6 \mathrm{H}_{2} \mathrm{O}(100)$ & 75.8 & 0.0 & $100.0 / 0.0$ \\
\hline
\end{tabular}

${ }^{\mathrm{a}} \mathrm{A}$ mixture of cyclohexanone oxime $(0.5 \mathrm{mmol})$ and cobalt salt $(10 \mathrm{~mol} \%)$ was stirred in $\mathrm{MeCN}(1.0 \mathrm{~mL})$ at $80^{\circ} \mathrm{C}$ for $2 \mathrm{~h}$.

By combined use of a cobalt salt and a Lewis acid, it was found that the conversion rate was remarkably improved (Table 3). The yield of 2 was better than the case of $25 \mathrm{~mol} \%$ added cobalt salt shown in Table 2 . The Beckmann rearrangement is promoted by the cobalt salt coordinated to the nitrogen atom of the cyclohexanone oxime (1).

In Table 4 summarizes the results of cobalt salt/Lewis acid-catalyzed reactions of cyclohexanone oxime (1) to $\varepsilon$-caprolactam (2). Individual uses of a catalytic amount of cobalt perchlorate and ytterbium trifluoromethanesulfonate are less effective in the Beckmann rearrangement of the oxime 1, as shown in Table 1. It is surprising that the combined use of those salts provides a noted enhancement in their catalytic activity to give the lactam 2 in $74.1 \%$ yield. The combination of cobalt perchlorate and samarium trifluoromethanesulfonate gave the lactam 2 in $80.6 \%$ yield. Even a cobalt salt, such as cobalt carbonate, having no ability as a catalyst for the Beckmann rearrangement, a combination with samarium trifluoromethanesulfonate or ytterbium trifluoromethanesulfonate made it a valued catalyst to give the lactam 2 . Cobalt chloride and nitrite were also efficient co-catalysts for this reaction, and it was shown that the property for Lewis acid was not absolutely necessary for cobalt co-catalysts.

For liquid phase Beckmann rearrangement, cyclooctanone oxime (6) is a less reactive substrate in the presence of various organic catalysts [13] [19]. The combined use of cobalt salts and Lewis acids is quite effective for the Beckmann rearrangement of the oxime 6 to 2-azacyclononanone (7) in the same case of cyclohexanone oxime (1). Cobalt chloride has no ability as a catalyst for preparation of the lactam $\mathbf{7}$ from the oxime $\mathbf{6}$, as shown in Table 5. A catalytic amount (10 mol\%) of ytterbium trifluoromethanesulfonate gave 2-azacyclononanone (7) in $36.9 \%$ yield. The combined use of cobalt chloride and ytterbium trifluoromethanesulfonate provides a noted enhancement in their catalytic activity to give the lactam 7 in $71.6 \%$ yield. Cobalt tetrafluoroborate is a best cocatalyst for ytterbium trifluoromethanesulfonate. Although samarium trifluoromethanesulfonate itself is less effective as a Lewis acid catalyst for the oxime $\mathbf{6}$ than ytterbium trifluoromethanesulfonate, samarium trifluoromethanesulfonate/cobalt tetrafluoroborate gave the lactam 7 in a higher yield. After stirring with a catalytic amount samarium trifluoromethanesulfonate/cobalt perchlorate for 2 hours at $80^{\circ} \mathrm{C}$, the oxime 6 was not de- 
Table 3. Effect of catalyst (cobalt salt and Lewis acid) ${ }^{\mathrm{a}}$.

\begin{tabular}{|c|c|c|c|c|c|}
\hline \multirow{2}{*}{ Entry } & \multirow{2}{*}{ Cobalt salt } & \multirow{2}{*}{ Lewis acid } & \multicolumn{2}{|c|}{ Yield/\% } & \multirow{2}{*}{$\begin{array}{c}\text { Selectivity } \\
\mathbf{2} / \mathbf{1}\end{array}$} \\
\hline & & & 2 & 1 & \\
\hline 1 & $\mathrm{Co}\left(\mathrm{BF}_{4}\right)_{2} \cdot 6 \mathrm{H}_{2} \mathrm{O}$ & - & 10.3 & 32.0 & $24.3 / 75.7$ \\
\hline 2 & - & $\mathrm{Sm}(\mathrm{OTf})_{3}$ & 1.2 & 76.6 & $1.5 / 98.5$ \\
\hline 3 & $\mathrm{Co}\left(\mathrm{BF}_{4}\right)_{2} \cdot 6 \mathrm{H}_{2} \mathrm{O}$ & $\mathrm{Sm}(\mathrm{OTf})_{3}$ & 69.6 & 21.1 & 76.7/23.3 \\
\hline 4 & - & $\mathrm{Yb}(\mathrm{OTf})_{3}$ & 4.8 & 79.1 & $5.7 / 94.3$ \\
\hline 5 & $\mathrm{Co}\left(\mathrm{BF}_{4}\right)_{2} \cdot 6 \mathrm{H}_{2} \mathrm{O}$ & $\mathrm{Yb}(\mathrm{OTf})_{3}$ & 68.3 & 24.1 & 73.9/26.1 \\
\hline
\end{tabular}

${ }^{\mathrm{a}} \mathrm{A}$ mixture of cyclohexanone oxime $(0.5 \mathrm{mmol})$, cobalt salt $(10 \mathrm{~mol} \%)$, and Lewis acid $(10 \mathrm{~mol} \%)$ was stirred in $\mathrm{MeCN}(1.0 \mathrm{~mL})$ at $80^{\circ} \mathrm{C}$ for $2 \mathrm{~h}$.

Table 4. Beckmann rearrangement of cyclohexanone oxime (1) by combined use of cobalt salts and Lewis acids ${ }^{\mathrm{a}}$.

\begin{tabular}{|c|c|c|c|c|c|}
\hline \multirow{2}{*}{ Entry } & \multirow{2}{*}{ Cobalt salt } & \multirow{2}{*}{ Lewis acid } & \multicolumn{2}{|c|}{ Yield/\% } & \multirow{2}{*}{$\begin{array}{c}\text { Selectivity } \\
\mathbf{2} / \mathbf{1}\end{array}$} \\
\hline & & & 2 & 1 & \\
\hline 1 & $\mathrm{CoCO}_{3}$ & $\operatorname{Sm}(\mathrm{OTf})_{3}$ & 9.7 & 81.0 & $10.7 / 89.3$ \\
\hline 2 & $\mathrm{Co}\left(\mathrm{NO}_{3}\right)_{2} \cdot 6 \mathrm{H}_{2} \mathrm{O}$ & $\operatorname{Sm}(\mathrm{OTf})_{3}$ & 47.8 & 42.3 & $53.0 / 47.0$ \\
\hline 3 & $\mathrm{CoCl}_{2}$ & $\mathrm{Sm}(\mathrm{OTf})_{3}$ & 55.0 & 35.8 & $60.6 / 39.4$ \\
\hline 4 & $\mathrm{Co}\left(\mathrm{BF}_{4}\right)_{2} \cdot 6 \mathrm{H}_{2} \mathrm{O}$ & $\operatorname{Sm}(\mathrm{OTf})_{3}$ & 69.6 & 21.1 & $76.7 / 23.3$ \\
\hline 5 & $\mathrm{Co}\left(\mathrm{ClO}_{4}\right)_{2} \cdot 6 \mathrm{H}_{2} \mathrm{O}$ & $\mathrm{Sm}(\mathrm{OTf})_{3}$ & 80.6 & 5.6 & 93.5/6.5 \\
\hline 6 & $\mathrm{CoCO}_{3}$ & $\mathrm{Yb}(\mathrm{OTf})_{3}$ & 14.7 & 75.6 & $16.3 / 83.7$ \\
\hline 7 & $\mathrm{Co}\left(\mathrm{NO}_{3}\right)_{2} \cdot 6 \mathrm{H}_{2} \mathrm{O}$ & $\mathrm{Yb}(\mathrm{OTf})_{3}$ & 52.1 & 37.6 & $58.7 / 41.3$ \\
\hline 8 & $\mathrm{CoCl}_{2}$ & $\mathrm{Yb}(\mathrm{OTf})_{3}$ & 73.1 & 16.8 & 81.3/18.7 \\
\hline 9 & $\mathrm{Co}\left(\mathrm{BF}_{4}\right)_{2} \cdot 6 \mathrm{H}_{2} \mathrm{O}$ & $\mathrm{Yb}(\mathrm{OTf})_{3}$ & 68.3 & 24.1 & 73.9/26.1 \\
\hline 10 & $\mathrm{Co}\left(\mathrm{ClO}_{4}\right)_{2} \cdot 6 \mathrm{H}_{2} \mathrm{O}$ & $\mathrm{Yb}(\mathrm{OTf})_{3}$ & 74.1 & 19.0 & $79.5 / 20.5$ \\
\hline
\end{tabular}

${ }^{\mathrm{a}} \mathrm{A}$ mixture of cyclohexanone oxime $(0.5 \mathrm{mmol})$, cobalt salt $(10 \mathrm{~mol} \%)$, and Lewis acid $(10 \mathrm{~mol} \%)$ was stirred in $\mathrm{MeCN}(1.0 \mathrm{~mL})$ at $80^{\circ} \mathrm{C}$ for $2 \mathrm{~h}$.

tected in the reaction mixture and the isolated yield of the lactame 7 attained as high as $96.6 \%$.

The possible reaction mechanism will be speculated, the Beckmann rearrangement will have been accelerated by a cobalt salt is coordinated on the nitrogen atom, and a Lewis acid coordinated on the oxygen will be predicted from this result (Figure 2).

\section{Conclusion}

The combination of a variety of cobalt salts and Lewis acids serves as an efficient catalyst for the Beckmann rearrangement of cycloalkanone oximes to the corresponding lactams, which was not fully succeeded by cyanuric chloride and triphosphazene due to the low reactivity of the oximes. Cobalt salts blocked the coordination of the oxime to the Lewis acid through the nitrogen atom, and made a firm coordination between the Lewis acid and the oxygen atom in the cyclohexanone oxime. Choosing cobalt salt to make a combined catalyst with a higher efficiency is very important for this reaction. Although a common work-up with aqueous base was also favorable for our catalytic rearrangement reaction to dissociate the lactams from the catalysts, it made it possible to reduce the production of undesirable byproducts. The present method provides a low environmental load process to the lactams while avoiding the energy cost explosion.

\section{Experimental}

\subsection{General}

NMR spectra were recorded on a JEOL JNM-GSX500 spectrometer. The NMR studies were carried out using 


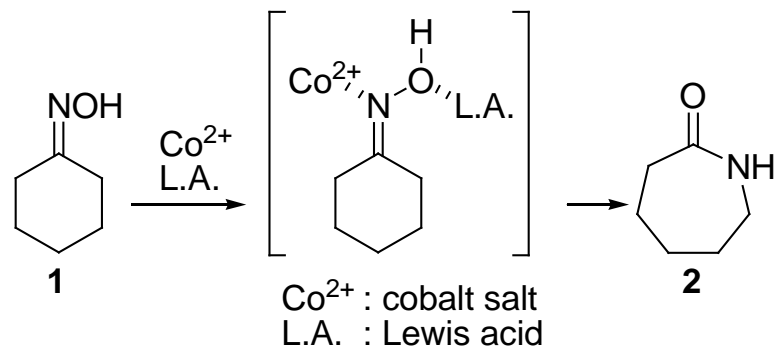

Figure 2. Protonation of cyclohexanone oxime (1).

Table 5. Beckmann rearrangement of cyclooctanone oxime (6) by combined use of cobalt salts and Lewis acids .

\begin{tabular}{|c|c|c|c|c|c|}
\hline \multirow{2}{*}{ Entry } & \multirow{2}{*}{ Cobalt salt } & \multirow{2}{*}{ Lewis acid } & \multicolumn{2}{|c|}{ Yield/\% } & \multirow{2}{*}{$\begin{array}{c}\text { Selectivity } \\
\mathbf{7 / 6}\end{array}$} \\
\hline & & & 7 & 6 & \\
\hline 1 & $\mathrm{Co}\left(\mathrm{NO}_{3}\right)_{2} \cdot 6 \mathrm{H}_{2} \mathrm{O}$ & - & 0.0 & 98.0 & $0.0 / 100.0$ \\
\hline 2 & $\mathrm{CoCl}_{2}$ & - & 0.0 & 78.9 & $0.0 / 100.0$ \\
\hline 3 & $\mathrm{Co}\left(\mathrm{BF}_{4}\right)_{2} \cdot 6 \mathrm{H}_{2} \mathrm{O}$ & - & 5.8 & 81.4 & 6.7/93.3 \\
\hline 4 & $\mathrm{Co}\left(\mathrm{ClO}_{4}\right)_{2} \cdot 6 \mathrm{H}_{2} \mathrm{O}$ & - & 1.1 & 95.9 & $1.1 / 98.9$ \\
\hline 5 & - & $\mathrm{Sm}(\mathrm{OTf})_{3}$ & 8.4 & 89.9 & 8.6/91.4 \\
\hline 6 & $\mathrm{Co}\left(\mathrm{NO}_{3}\right)_{2} \cdot 6 \mathrm{H}_{2} \mathrm{O}$ & $\mathrm{Sm}(\mathrm{OTf})_{3}$ & 11.1 & 86.5 & 11.4/88.6 \\
\hline 7 & $\mathrm{CoCl}_{2}$ & $\operatorname{Sm}(\mathrm{OTf})_{3}$ & 47.0 & 31.9 & $59.5 / 40.5$ \\
\hline 8 & $\mathrm{Co}\left(\mathrm{BF}_{4}\right)_{2} \cdot 6 \mathrm{H}_{2} \mathrm{O}$ & $\mathrm{Sm}(\mathrm{OTf})_{3}$ & 89.0 & 8.5 & 91.2/8.8 \\
\hline 9 & $\mathrm{Co}\left(\mathrm{ClO}_{4}\right)_{2} \cdot 6 \mathrm{H}_{2} \mathrm{O}$ & $\mathrm{Sm}(\mathrm{OTf})_{3}$ & 96.6 & 0.0 & $100.0 / 0.0$ \\
\hline 10 & - & $\mathrm{Yb}(\mathrm{OTf})_{3}$ & 36.9 & 62.1 & $37.2 / 62.8$ \\
\hline 11 & $\mathrm{Co}\left(\mathrm{NO}_{3}\right)_{2} \cdot 6 \mathrm{H}_{2} \mathrm{O}$ & $\mathrm{Yb}(\mathrm{OTf})_{3}$ & 57.4 & 28.4 & 66.9/33.1 \\
\hline 12 & $\mathrm{CoCl}_{2}$ & $\mathrm{Yb}(\mathrm{OTf})_{3}$ & 71.6 & 26.0 & 73.4/26.6 \\
\hline 13 & $\mathrm{Co}\left(\mathrm{BF}_{4}\right)_{2} \cdot 6 \mathrm{H}_{2} \mathrm{O}$ & $\mathrm{Yb}(\mathrm{OTf})_{3}$ & 76.8 & 15.7 & 83.1/16.9 \\
\hline 14 & $\mathrm{Co}\left(\mathrm{ClO}_{4}\right)_{2} \cdot 6 \mathrm{H}_{2} \mathrm{O}$ & $\mathrm{Yb}(\mathrm{OTf})_{3}$ & 63.1 & 22.9 & $73.4 / 26.6$ \\
\hline
\end{tabular}

${ }^{\mathrm{a}} \mathrm{A}$ mixture of cyclooctanone oxime $(0.5 \mathrm{mmol})$, cobalt salt $(10 \mathrm{~mol} \%)$, and Lewis acid $(10 \mathrm{~mol} \%)$ was stirred in $\mathrm{MeCN}(1.0 \mathrm{~mL})$ at $80^{\circ} \mathrm{C}$ for $2 \mathrm{~h}$.

$\mathrm{CDCl}_{3}$ as solvent and tetramethylsilane was used as internal reference.

\subsection{Beckmann Rearrangement}

The general procedure for the Beckmann rearrangements of a cycloalkanone oxime to the corresponding lactam is as follows: a mixture of cycloalkanone oxime $(55.6 \mathrm{mg}, 0.5 \mathrm{mmol})$ and the catalysts in acetonitrile $(1 \mathrm{~mL})$ was stirred for $2 \mathrm{~h}$ at $80^{\circ} \mathrm{C}$ under $\mathrm{N}_{2}$. The mixture was diluted with ethyl acetate $(10 \mathrm{~mL})$, added $\mathrm{NaCl}$-saturated $0.4 \mathrm{~mol} / \mathrm{dm}^{3} \mathrm{NaOH}(2 \mathrm{~mL})$, and evaporated under reduced pressure to dryness. The residue was washed with dichloromethane $(50 \mathrm{~mL} \times 2)$ and the mixture was evaporated under reduced pressure. The produced products were determined by the comparison with the commercially available chemicals. $\varepsilon$-Caprolactam (2): ${ }^{1} \mathrm{H}$ NMR $\left(\mathrm{CDCl}_{3}\right) \delta 1.62-1.80(\mathrm{~m}, 6 \mathrm{H}), 2.44-2.49(\mathrm{~m}, 2 \mathrm{H}), 3.18-3.24$ (m, 2H), 5.49 (br, 1H). 2-Azacyclononanone (7): ${ }^{1} \mathrm{H}$ NMR (CDCl $)$ d 1.43 - 1.88 (m, 10H), 2.40 - 2.46 (m, 2H), 3.33-3.39 (m, 2H), 5.73 (br, 1H).

\section{References}

[1] Gawley, R.E. (2004) The Beckmann Reactions: Rearrangements, Elimination-Additions, Fragmentations, and Rearrangement-Cyclizations. Organic Reactions, 35, 1-420. http://dx.doi.org/10.1002/0471264180.or035.01 
[2] Smith, M.B. and March, J. (2007) March's Advanced Organic Chemistry. 6th Edition, John Wiley \& Sons, Inc., Hoboken, 1613-1616.

[3] Kaur, N., Sharma, P. and Kishore, D. (2012) Application of Different Catalysts in Beckmann Rearrangement. Journal of Chemical and Pharmaceutical Research, 4, 1938-1946.

[4] Zhang, J.S., Riaud, A., Wang, K., Lu, Y.C. and Luo, G.S. (2014) Beckmann Rearrangement of Cyclohexanone Oxime to $\varepsilon$-Caprolactam in a Modified Catalytic System of Trifluoroacetic Acid. Catalysis Letters, 144, 151-157. http://dx.doi.org/10.1007/s10562-013-1114-3

[5] Rancan, E., Aricò, F., Quartarone, G., Ronchin, L., Tundo, P. and Vavasori A. (2014) Self-Catalyzed Direct Amidation of Ketones: A Sustainable Procedure for Acetaminophen Synthesis. Catalysis Communications, 54, 11-16. http://dx.doi.org/10.1016/j.catcom.2014.05.007

[6] Mao, D., Long, Z., Zhou, Y., Li, J., Wang, X. and Wang, J. (2014) Dual-Sulfonated Dipyridinium Phosphotungstate Catalyst for Liquid-Phase Beckmann Rearrangement of Cyclohexanone Oxime. RSC Advances, 4, 15635-15641. http://dx.doi.org/10.1039/c4ra00552j

[7] Opanasenko, M., Shamzhy, M., Lamač, M. and Čejka, J. (2013) The Effect of Substrate Size in the Beckmann Rearrangement: MOFs vs. Zeolites. Catalysis Today, 204, 94-100. http://dx.doi.org/10.1016/j.cattod.2012.09.008

[8] Vaschetto, E.G., Monti, G.A., Herrero, E.R., Casuscelli, S.G. and Eimer, G.A. (2013) Influence of the Synthesis Conditions on the Physicochemical Properties and Acidity of Al-MCM-41 as Catalysts for the Cyclohexanone Oxime Rearrangement. Applied Catalysis A General, 453, 391-402. http://dx.doi.org/10.1016/j.apcata.2012.12.016

[9] Zuidhof, N.T., de Croon, M.H.J.M., Schouten, J.C. and Tinge, J.T. (2013) Beckmann Rearrangement of Cyclohexanone Oxime in a Microreactor Setup with Internal Recirculation. Chemical Engineering \& Technology, 36, 13871394. http://dx.doi.org/10.1002/ceat.201300088

[10] Bellussi, G. and Perego, C. (2000) Industrial Catalytic Aspects of the Synthesis of Monomers for Nylon Production. CATTECH, 4, 4-16. http://dx.doi.org/10.1023/A:1011905009608

[11] Maia, A., Albanese, D.C.M. and Landini, D. (2012) Cyanuric Chloride Catalyzed Beckmann Rearrangement of Ketoximes in Biodegradable Ionic Liquids. Tetrahedron, 68, 1947-1950. http://dx.doi.org/10.1016/j.tet.2011.12.051

[12] De Luca, L., Giacomelli, G. and Porcheddu, A. (2002) Beckmann Rearrangement of Oximes under Very Mild Conditions. The Journal of Organic Chemistry, 67, 6272-6274. http://dx.doi.org/10.1021/jo025960d

[13] Furuya, Y., Ishihara, K. and Yamamoto, H. (2005) Cyanuric Chloride as a Mild and Active Beckmann Rearrangement Catalyst. Journal of the American Chemical Society, 127, 11240-11241. http://dx.doi.org/10.1021/ja053441x

[14] Hashimoto, M., Obora, Y., Sakaguchi, S. and Ishii, Y. (2008) Beckmann Rearrangement of Ketoximes to Lactams by Triphosphazene Catalyst. The Journal of Organic Chemistry, 73, 2894-2897. http://dx.doi.org/10.1021/jo702277g

[15] Kim, J., Park, W. and Ryoo, R. (2011) Surfactant-Directed Zeolite Nanosheets: A High-Performance Catalyst for GasPhase Beckmann Rearrangement. ACS Catalysis, 1, 337-341. http://dx.doi.org/10.1021/cs100160g

[16] An, N., Tian, B.-X., Pi, H.-J., Eriksson, L.A. and Deng, W.-P. (2013) Mechanistic Insight into Self-Propagation of Organo-Mediated Beckmann Rearrangement: A Combined Experimental and Computational Study. The Journal of Organic Chemistry, 78, 4297-4302. http://dx.doi.org/10.1021/jo400278c

[17] Hori, K., Sumimoto, M. and Yamamoto, H. Unpublished Data.

[18] Coşkun, A. and Koç, Z.E. (2007) Synthesis and Characterization of New Vic-Dioximes and Their Metal Complexes with $\mathrm{Cu}(\mathrm{II}), \mathrm{Ni}(\mathrm{II})$, and Co(II) Salts. Russian Journal of Coordination Chemistry, 33, 184-189. http://dx.doi.org/10.1134/S1070328407030050

[19] Shibamoto, A., Iwahama, T. and Nakano, T. (2008) PCT International Application No. 2008078642. 